Haya: The Saudi Journal of Life Sciences

Abbreviated Key Title: Haya Saudi J Life Sci

ISSN 2415-623X (Print) |ISSN 2415-6221 (Online)

Scholars Middle East Publishers, Dubai, United Arab Emirates

Journal homepage: https://saudijournals.com

Original Research Article

\title{
Capital Utilization for Livelihoods among Households with People Living With HIV/AIDS in Kaduna State North-West, Nigeria
}

Suleiman Mohammed Saeed ${ }^{1}$, Dusadee Ayuwat ${ }^{2 *}$

${ }^{1}$ Ph.D. Candidate of Sociology, Department of Social Sciences, Division of Sociology and Anthropology, Khon Kaen University, Khon Kaen, Thailand/ Federal University, Gashua, Yobe State, Nigeria

${ }^{2}$ Ph.D., Professor, Labour and International Migration Service Center, Department of Social Sciences, Division of Sociology and Anthropology, Khon Kaen University, Khon Kaen, Thailand

DOI: $10.36348 /$ sjls.2021.v06i03.002 $\quad$ | Received: 24.02.2021 | Accepted: 08.03.2021 | Published: 30.03 .2021

*Corresponding author: Dusadee Ayuwat

\section{Abstract}

This research work seeks to explore the capitals utilization for livelihoods among households with People Living with HIV/AIDS (PLWHA) in Kaduna State, North West, Nigeria. The study adopts a qualitative procedural and explicitly phenomenological in nature and employed in-depth interviews, participatory and non-participatory observations as research tool. The interview period of conducting the fieldwork was from August to November, 2019 and twenty-one households with PLWHA in Kaduna State, North West, Nigeria were utilized as the qualified target. This research results discovered that households with PLWHA utilized a range of capitals for their livelihoods and created their livelihoods patterns based on their available capitals. The findings revealed that there are five types of capitals as resources utilized by households with PLWHA to fashioning out their livelihoods patterns and such capitals are social capital for resolving households difficulties and participating in the villages activities; financial capital utilized by households for investments and land accretions; human capital like knowledge and know-how useful in their line of businesses to maintain their households; natural and physical capitals that are utilized as means to make every effort to make living like cutting trees for cooking and selling, collecting of herbs from the forest for medication, road network among other things. Based on the findings of this study, it is recommended that authorities need to train households with PLWHA on how to enhance their capacities on livelihoods capitals utilization effectively. The government should come up with policies that can take care and support the livelihood hood activities of households with PLWHA.

Keywords: Capitals, HIV/AIDS, Households with PLWHA, Kaduna, Livelihoods, Utilization.

Copyright (C) 2021 The Author(s): This is an open-access article distributed under the terms of the Creative Commons Attribution 4.0 International License (CC BY-NC 4.0) which permits unrestricted use, distribution, and reproduction in any medium for non-commercial use provided the original author and source are credited.

\section{INTRODUCTION}

Livelihood capitals have significant impact on the livelihood preferences and income of households with People Living with HIV/AIDS (PLWHA). Capitals and its accumulation play significantly function in the livelihood activities of households with PLWHA as illustrated by Ayuwat, Saithong and Chinnasri [1] that secured capital accumulation can lead to good economic activities or practice to boost their living conditions of households.

It is vital to identify capitals that play the most decisive role in the development of sustainable livelihoods along with income generation for households with PLWHA which helps to provide more reliable options on how to cope, sustain the shock and stress of the HIV/AIDS pandemic on the livelihoods of households with PLWHA.
Households with PLWHA are expected to fine-tune their livelihood activities as observed by Ayuwat and Chamarattana [2] in order for households to adjust themselves to cope with numerous challenges facing them such as work allocation within households and managing debts which are common to households with PLWHA. Similarly, from the preceding studies, it shows that to effectively adjust to living with the epidemic, PLWHA and their households require to have secured livelihoods both material resources such as food and capitals to take care of a number of the additional basic needs [3]. Similarly, it is observed that, to ameliorate the shock and stress of households with PLWHA, it is significant in tackling HIV/AIDS epidemic and associated socioeconomic challenges which are essentially overturning the descending spiral of livelihood deprivation and boost the affected households towards higher earnings as well as 
contributing to the sustainable development of the affected communities [4-6].

It is observed that households with PLWHA in Nigeria are facing numerous challenges due to shock and stress of HIV/AIDS epidemic but still engage in a number of livelihood activities since livelihood capitals utilization is an influencing factor in incomes generation as noted by Truong, Hall and Garry [7] that accessibility to capitals is important for households livelihood activities and lack of livelihood capitals restrict the incomes of households. To this end, households with PLWHA utilized various capitals available to them to diversified their livelihood activities and sustain their households members as observed.

It is essential to mention that prior to and after the manifestations of the HIV/AIDS pandemic, the households' allocations are capitals like human, social, natural, physical and financial respectively and the households have intensified the utilization of these capitals after the manifestation of the pandemic due to its consequences on the livelihood practices and capitals. Hence, households with PLWHA in spite of the shock and stress of managing household members living with pandemic have to engage in livelihood patterns alongside utilizing numerous forms of household capitals to generate income. Thus, this paper explored the utilization of capitals for livelihood among households with PLWHA in Kaduna State, North West, Nigeria.

\section{Related Concepts and Studies}

This study employed the notion of capitals as its main concept to investigate Capital Utilization for Livelihoods among Households with People Living with HIV/AIDS in Kaduna State North-West, Nigeria. Thus, it is worth mentioning that the concept of capital is regarded as an interdisciplinary concept and used by many fields of endeavours and capitals accumulation are essential to the living conditions of households with PLWHA. Thus, this research reviewed the following key terms related to capital utilization:

Human capital is a transformation of knowledge, habits, social behaviour and personality that add to economic gains for a person, household or community, this knowledge can be accomplished all the way through education, inventiveness, availability of skillfulness and ability, know-how, instruction and exposure, human capital also consists of health of an individual, household, and community [8].

Social capital takes a key function in the development of a person; institution, and community, social capital can be illustrated as the interactions, traditions, and norms that characterize the group relations. Social networks are painstaking as straight links involving people, which boost efficiency by dropping the overheads of undertaking commerce and make easy bringing together and collaboration, links, and ties inside a community are required to provide a system of distinctiveness and rationale to these communities, and equally binds the foundation of getting information that can be of immense support to the community [9].

Natural capital is the centre of the entire individual economic accomplishment. Natural capital consists of land, water, air, living organisms and all ecosystems essential for the human being continued existence and comfort. In a wide-ranging, natural capital denotes all natural resources $[10,8,9]$. Natural capital is the natural resource or asset of the stocks and environmental services that can be valuable for the source of livelihoods, natural vital is significant to people who achieve part or all of their livelihoods from resource-based activities like farming, livestock among others.

Physical capital is an asset or resource with the purpose of facilitates to revolve unrefined resources into refined goods or commodities, it consists of the essential infrastructure and produced commodities to maintain livelihoods, these infrastructures consist of transformation to the physical environment that can facilitate individuals to congregate their vital requirements and become more industrious to improve their means of life, physical capital comprises of implements and apparatus that individuals utilize to function more industriously [9].

Financial or Economic capital is the financial assets that individuals exploit to accomplish their source of revenue activities, it is used by people to stout their life in order to contribute to their consumption and production, it is any liquid means or system that symbolize wealth like cash, purchasable items, investments, credit, or described as saved-up capital that is able to be employed to turn on or safeguard a commerce. Carney [11] posited that accessibility of capital permit for the expansion of big business through innovation, diversification and skill development; appealing in the performance that will support making earnings and capitals required by the households.

The capitals such as natural, physical, social, financial and human capitals that the households with PLWHA need in order to have enough income for survival due to the shock and stress of the epidemic. Households with PLWHA need the above-mentioned assets to be able to have a good life. Financial capital is needed for households with PLWHA to be able to fund the treatment of their patients and buy food that has the right nutrients for their survival. The livelihood resources refer to anything that people derive their income from. It can also be looked at as anything that an individual can invest to increase their flow of income or consumption. When people infected with HIV/AIDS 
have better access to assets then the outcome is very desirable. The more capitals any household with PLWHA has admittance to, the smaller they will be vulnerable to the hit of trends and shocks and their livelihoods will also be more secured. An enhancement in one capital leads to an enhancement in another, the more educated PLWHA become (human capital), and the more likely they are to get a good job with good pay. The good pay means an increase in the financial capital of the households with PLWHA. Increase in financial capital, meaning that the households with PLWHA will upgrade their home with better facilities (increase in physical capital). To be able to achieve sustainable livelihoods for households with PLWHA in Kaduna Town, North West, Nigeria, accessibility to various capitals in order to meet up with their basic requirements of life are very crucial.

\section{METHODS}

This study adopts a qualitative procedural and explicitly phenomenological in nature and employed indepth interviews, participatory and non-participatory observations as research tool. The interview period of conducting the fieldwork was from August to November, 2019 and twenty-one households with PLWHA in Northern Nigeria were utilized as the qualified target. This study utilized Kaduna State which is one of the states with the highest prevalence rate of PLWHA and it was also the capital of the defunct Northern Nigeria Region with various diverse people. It is essential to declare that many households in the research settings are into subsistence agriculture and engage in mixed farming systems and commercial farming also. The main food crops in the study sites are maize, sweet potatoes, beans, sugar canes, millets, and vegetables among other crops. Likewise, several households engage in trading, driving, livestock, fishing, food vendors' government and seasonal jobs among others as means of sustaining their livelihoods.

\section{RESULTS}

\section{Context of Households with PLWHA}

The working characteristics of the Barnawa village differ in nature to that of Kakuri Gwari and Television owing to the fact of the geographical advantages as well as the levels of government support available to the three communities.

\section{Working Characteristics of Households in Barnawa, Kakuri Gwari and Television Villages}

Barnawa village is having more geographical advantages as well as supporting facilities such as roads, health centres, schools, markets closer to the villagers. The village is having good soil quality for agriculture in planting crops like maize, sugar cane, potatoes and vegetables among others. While in Kakuri Gwari and Television villages the livelihoods are different as well as different working characteristics. The geographical suitability such as closeness to river and more accessibility to land for farming make the people of Barnawa village into agriculture practices and rearing of animals like goats, sheep and rams while the people of Kakuri Gwari and Television villages are also into farming and rearing of pigs and dogs as well as take other seasonal jobs.

The people of Barnawa village are mainly civil servants, farmers and business men/women. In view of the nature of the livelihoods, this study described the agricultural practices of the people of the village since most of the households with PLWHA engage in farming in order to sustain PLWHA. It is pertinent to note that the daily activities of the farmers are quite different from that of the traders, civil servants and business men/women.

The daily activities of the government workers, traders and transporters are also are different; the villagers who engage in each of these livelihoods have different schedules. However, despite some of these villagers are still government workers, traders or transporters, they still engage in farming as means of getting additional income to take care of the PLWHA. The traders work different hours to people who work with government or transporters. The traders in the village work together with members of their households while those working with government go their workplaces and transporters go out for their transporting services they render to people. It is vital to state that those people who are transporters can be divided into two, those who own the vehicles and those who are just mere drivers.

The people of Kakuri Gwari and Television village have diverse working characteristics in each huddle. Agricultural practices and seasonal jobs are major supporting livelihoods in the villages. The farm products are sold on the street and markets. The working characteristics or supporting livelihoods in Kakuri Gwari and Television comprising farming, rearing of pigs and dogs, selling of vegetables, fruits, sugarcanes, food vendors, casual workers in the companies, transporters in order to get more income to take care of PLWHA. It is important to mention that the daily activities of the villagers are divided based on their working characteristics. It is pertinent to note that the daily activities of the farmers are quite different from that of those selling vegetables, fruits, sugarcanes, maize, food vendors, casual workers in the companies, transporters.

The farmers work from $7 \mathrm{am}$ to $5 \mathrm{pm}$; subsequently the farmers take a break and go for other activities in the villages and the conditions of the people of the villages housing pattern are at variance, the farmers with 0.5 to 1 hectare of land are having lower housing conditions compare with the farmers who possess more than 1 hectare of land. The poor farmers with 0.5 to 1 hectare of land have mud houses but no televisions while those well-heeled farmers who are 
having more than 1 hectare of land have block houses with televisions, they have motor cycles and cars.

The daily activities of the selling vegetables, fruits, sugarcanes, maize, food vendors, casual workers in the companies, transporters, government workers are also different; the villagers who engage in each of these livelihoods have different routine. Conversely, notwithstanding some of these villagers are still government workers, selling of vegetables, fruits, sugarcanes, maize, food vendors, casual workers in the companies, transporters, they still engage in farming. The sellers of vegetables, fruits, sugarcanes, maize, food vendors, casual workers in the companies, transporters work different hours to people who work with government or transporters. It is vital to state that those people who are transporters can be divided into two, those who own the vehicles and those who are just drivers.

Thus, it important to state that the socioeconomic divergence within the working groups in three villages bring about the different welfare levels regarding households in these villages and by implication it is worth noting that some of the households with PLWHA are able to manage their remittances effectively and successfully while some of the households with PLWHA unable to manage their remittances efficiently or successfully in spite of the shock and stress of the HIV/AIDS pandemic. It is observed that some households with PLWHA spent their money on activities that were of little or no benefit to them and by implication, some of the households with PLWHA failed to escape from hardship and poverty.

It is pertinent to mention that in order to sustain the households, households with PLWHA get different incomes to survive, cope from shock and stress of the HIV/AIDS pandemic, and therefore, households with PLWHA were categorized into three categories as follows:

\section{The Strong Households}

These kinds of households are living a comfortable and secured life as they get expected remittances and the money received are utilized for savings or investment for the households such as buying and selling of lands. The households with PLWHA who fall under this category have cordial relationship in the villages; they live in peace and harmony with people in the villages. These households have the opportunity or advantage to cope with the challenges of HIV/AIDS epidemic in order to sustain the households despite some of them still live extravagant life.

\section{The Unpredictable Households}

These types of' households are living in a good way but not as the strong households while the members of these households bring back remittances but not always. It is observed that these kinds of households don't get income regularly as expected and by implication, the members of these households are still struggling to cope with the challenges of HIV/AIDS pandemic in order to sustain the households. It is worth noting that, some of these households could hardly manage their resources appropriately such as spending on extravagantly on clothes, shoes, wrist watches among others and by implication, some of these households with PLWHA failed to get income regularly and hardly manage the household income and invest on behalf of the households couple with the challenges of HIV/AIDS pandemic in order to sustain the households.

\section{The Weak Households}

These kinds of households struggle to live, the living circumstances of these cluster of households are complex or complicated because they hardly get remittance and some of the members of these of households experienced depressing working circumstances. These types of households hardly get incomes to manage their households' couple with the shock and stress of the HIV/AIDS pandemic; they find it difficult to meet up with their medical expenses and other households' basic needs and by implication, these types of households with PLWHA failed to escape from hardship and poverty.

\section{Capitals Utilization for Livelihoods among Households with PLWHA}

This study observed the types of capitals available to households with PLWHA as their mechanisms for their livelihoods survival such assets comprising capitals like human, social, natural, physical and financial respectively. It is observed that each of the livelihood assets is used by the households with PLWHA to accomplish their livelihoods practices. To this end, the sustainable livelihoods make out five forms of assets or capitals in which livelihoods are put together, explicitly human, social, natural, physical and financial capitals. The livelihood assets refer to anything that people derive their income from. It can also be looked at as anything that an individual can invest to increase their flow of income or consumption. When people have better access to assets then the outcome is very desirable. The more assets any household has access to or the less they have access to will be strong or vulnerable to the impact, trends and shocks as observed by Ayuwat, Saithong and Chinnasri [1] that households with accumulated and well utilized capitals enable households to upgrade their occupational and educational status, attain enhanced economic status to improve their living conditions.

It is essential to mention that prior to and after the manifestations of the HIV/AIDS pandemic, the households' allocations are capitals like human, social, natural, physical and financial respectively and the 
households have intensified the utilization of these capitals after the manifestation of the pandemic due to its consequences on the livelihood practices and capitals, by implication, households with PLWHA through their daily activities to improve their means of livelihoods. To this end, it is observed that the livelihoods practices of the households with PLWHA may perhaps be analyzed through the relationship between livelihoods patterns and households capitals. The table 1 below depicts the types of capitals available to households for their livelihoods patterns:

Table-1: Type of Capitals

\begin{tabular}{|l|l|}
\hline Types of Capital & Qualitative Analysis Indicators \\
\hline Human Capital & $\begin{array}{l}\text { Access to Education } \\
\text { Level of Education } \\
\text { Skills } \\
\text { Knowledge } \\
\text { Cultural Beliefs }\end{array}$ \\
\hline Social Capital & $\begin{array}{l}\text { Kin Networking } \\
\text { Neighbourhood Networking } \\
\text { Group Networking }\end{array}$ \\
\hline Physical Capital & $\begin{array}{l}\text { Accessibility to Public Transportation } \\
\text { Accessibility to Road } \\
\text { Availability of Vehicle to Support Livelihood Activities } \\
\text { Equipment to Support Livelihoods Activities }\end{array}$ \\
\hline Natural Capital & $\begin{array}{l}\text { Knowledge and Awareness to Environment } \\
\text { Accessibility to Material to Support Livelihoods Activities }\end{array}$ \\
\hline Financial Capital & $\begin{array}{l}\text { Regular Inflows such as Income, transfer or remittance from Government } \\
\text { Cash and Liquid }\end{array}$ \\
\hline
\end{tabular}

Source: Qualitative Research, 2019

\section{Capitals Utilization for Savings and Land Accumulations}

The financial capital was a vital capital utilized by the households with PLWHA in order to sustain their livelihoods practices and manage the shock and stress of the pandemic. It is worth noting that the financial capital in forms of households' savings along with capitals accumulation was utilized to accomplish the livelihoods goals of the households with PLWHA. In addition, the remittance from livelihoods practices or activities were the primary source of the funds that supports the financial position of the households owing to the fact that for the most part households hardly generate adequate households income because of the limitations of holding lands or their lack of ability to have career opportunities within the community. One of the key informants revealed as follows:

"Households with PLWHA could hardly generate sufficient income, have savings and cash at hand because our household members inability to have employment chances and with limited land for farming"

It is vital to mention that the amount of remittance from the livelihood activities were utilized for medical expenses, provisions of foods, clothes, shelter, payments of school fees and other households bills. The households with PLWHA equally saved their remittance for the future or upcoming utilization while households with higher amount of remittance often invest their financial capital by engaging in the agricultural practices since it is common occupation in Nigeria as noted by one of the key informants that:
"Households with PLWHA invest their extra income especially in agricultural activities as means of households saving against the raining days to take care of the households' basic requirements when the needs arises"

It is worth noting that most households were in serious need of lands to conduct agricultural practices in order to generate additional incomes for households' utilization because some of the lands for farming purpose are turned to residence areas due to population explosion and industrial purpose and some of these industries have folded up.

In addition, financial capital in form of cooperative fund loans was available source for households with PLWHA and frequently utilized for livelihoods activities and investment in agricultural practices. It is also observed that households with PLWHA utilized others forms of capitals to support the utilization of financial capital to accomplish their goals such as a number of members of households with PLWHA bring into play their knowledge and skills in view of investing in a range of saving accounts, these skills come to being owing to the education acquired by the household members and the knowledge and skills utilized possibly will be regarded as the human capital that households employ to lessen the threat to households financial position. Similarly, social capital is another form of capital that households with PLWHA utilized by means of creating cooperative societies as networks possibly make access to savings chances, having cordial relationship with the people in the 
community for the purpose of accomplishing their desire of accumulating lands for their livelihoods and agricultural practices.

\section{Capitals Utilization for Conducting Career Opportunities}

This type of living pattern centred on human capital, it is crucial to mention that the human capital is an essential capital that enabled the households with PLWHA to survive during the shock and stress of the HIV/AIDS pandemic. Human capital is observed as the accumulated skills and experiences from the living activities of diverse contexts as noted by one of the key informants revealed that:

"Households with PLWHA receive the different types of skills acquisitions on how to improve their means of livelihoods in order to earn more income to reduce the burden of the HIV/AIDS on the households' earnings due to the huge medical expenses incurred by the households with PLWHA"

Households with PLWHA put into practice their human capital in a number of livelihoods or occupations such as their agricultural skills, their agricultural skills is a fundamental skill entrenched in the customary community production since agricultural practices is a common occupation in Nigeria, hence, the agricultural skills are transferred from one generation to another, therefore, the members of households with PLWHA posses the knowledge and skills for utilization in the agricultural practices for households survival.

In the same vein, the community equally received support from the government agencies and NGOs to promote the development of livelihoods skills such as training regarding agricultural practices and the carrying out these projects aid households with PLWHA complete access to the knowledge and skills essential for the career progress. It is observed that many households with PLWHA experienced the career supporting programmes as interventions from the government agencies and NGOs as noted by one of the key informants revealed that:

"Households with PLWHA receive little training from the government but the NGOs and FBOs are really trying to train us on different skills on farming and trading despite we are discouraged due to the negative attitude shown by the government agencies"

However, some of the households with PLWHA developed their own skills such as cultivating manure vegetables in their fields during the off farming seasons or by engaging in the seasonal jobs. Thus, the career supporting programmes promotes the households with PLWHA to produce their own career opportunities and improved their households' incomes away from relying solely on remittance alone. In addition, it was observed that a number of households with PLWHA transmit their skills among the household members internally such as learning skills of food processing and produced processed foods the neighbouring communities and as means of generating additional incomes.

It is also pertinent to state that convalescing skills and knowledge in the course of education can be considered as another human capital enhancement that is available for households with PLWHA because the education of the members of the households were put into action or practice the knowledge and skills acquired from the education institutions and within their households occupations such as some household members gain knowledge of mechanical skills at the vocational schools and apply these skills to establish their own mechanical garage in the village. Hence, human capital is utilized to develop the living skills and knowledge since school fees comes mainly from the remittance from the agricultural practices. It is important to mention that human capital is a crucial component for households' occupations; however, financial capital utilized by households is a blend of the remittances from the agricultural practices, cooperative loans and the carrying out of the physical capital such as households having a store or shop in their buildings for livelihood activities or renting out parts of their buildings out for livelihood activities.

\section{Capitals Utilization for Problem Solving and Communities Engagement}

Social capital is the primary capital utilized by households with PLWHA to access opportunities and social roles in the village or community. Social capital takes a key function in the development of a person; institution, and community, social capital can be illustrated as the interactions, traditions, and norms that characterize the group relations, thus, it is a relationship of trust, reciprocity and interactions. By implication, social capital highlighting the notion of livelihoods, network and relationship fashioned by social structures and social relationship among the actors. The main rationale behind social capital operation creates social networks to resolve households' predicaments or challenges such as the households' intra or inter disputes, farmers herdsmen disputes, these types of disputes can be resolved using personal relationship, community relationship and government officials as dispute resolving mechanism. Hence, it is observed that the social network is a component of a social capital derivative from a social structure based on the similar ethnic identity that later translated into a well-built social network within the village or community.

It is pertinent to mention that from observations, social network in the study areas or communities are vital, each household have relationship with relatives and this study establish from the head of villages and head of households who are parts of the key informant that despite the stigma attached to the HIV/AIDS epidemic that every household are related due to the fact that intermarriages are common and 
highly encourage in the villages and by implication, kin networking is strong and highly promoted. The villages' mechanism is lead by the head of the villages and the position is heredity from the same lineage. The head of the villages in all the study areas are called Dakace. Therefore, kin networking emerge to be the villages' livelihoods asset in carrying out their livelihoods activities in spite of the challenges being face by the households with PLWHA. A respondent revealed that:

"The kin networking is very important livelihoods asset for households with PLWHA, it is very strong in these communities due to intermarriages among them, therefore, kin networking is highly promoted"

To this end, it is also important to mention that social network is crucial in the villages were households members work in the neighborhood organizations as sponsor consumer relationship, while borrowing of household consumption goods within the neighborhood and teamwork in the households activities such as farming, rearing of animals, fetching water and firewood among others as parallel relationship. Social capital produced by households with PLWHA equally aid the access to resources in the villages like access to community occupations through the influences of the household status in the communities or villages, by implication, it is observed that social capital served as the vital capital in addition to supplementary capital for livelihoods and that make possible the households to get through any complicated circumstances in the villages or communities especially the shock and stress of the HIV/AIDS pandemic.

\section{Capitals Utilization for Households Survival}

It is observed that this kind of livelihood pattern centred on physical and natural capitals that show a relationship with one another. The physical capital symbolizes the resources fashioned out for households support production and infrastructural development for ever-increasing the natural capital utilization like provisions or constructions of roads, dams, among others. It is worth noting that households with PLWHA derived advantages from physical capital within the villages by taking advantages of the financial and human capitals of their households as well as utilizing or taking advantage of the public infrastructure such as using the roads for medical appointment, dam for farming for livelihood activities among others.

Regarding the availability of physical capital, the villages are having poor infrastructural facilities such as poor road accessibilities as one of their barriers even though the state government is planning to rehabilitate the poor roads in order to improve the road accessibilities as well as to ease movement of goods and services especially for households with PLWHA as observed by one respondent that:

"Poor road network is a general problem in Nigeria and it is really affecting the transportation of our goods as well as buying and selling, the government administrative policy is not favorable to contractors handling constructions of roads and heavy rain also delay constructions of roads"

Similarly, the challenges of shortage of dams make dry season farming very difficult and lead to insufficient production in the agricultural yields and low income. By implication having adverse effects on some households with PLWHA, finding it difficult to cope with the stress and shock of the pandemic as observed by one respondent:

"The shortage of dams for irrigation farming is seriously hindering the dry season farming causing poor production yields and reduction in the households with PLWHA income and by implication, the struggling households find it difficult to cope"

To this end, the villagers engaged in community services to create alternative temporary roads, pavements and small bridges where and when necessary in order to ease the movement or distribution of goods and services especially the farm products to the markets for the consumers or end users. Thus, the physical capital require materials or equipment to support the livelihoods activities of households with PLWHA not limited to affordability of them but also the future needs of those materials as physical capital. Regarding the households with PLWHA accessibility to capitals, especially the weak households with restricted access to other types of capitals, therefore, natural capital is crucial in helping these weak households to cope from the shock and stress of the HIV/AIDS pandemic such as the utilization of foods collected from the forest and herbs collected from the forest for medication as observed:

"Some of the households have to gathered herbs form the forest for Medication and also engage in cutting down trees for cooking and selling in order to meet up with the basic needs of their household members especially households with PLWHA that are facing the challenges of the epidemic"

To this end, it was observed that the natural capital available in the villages are informs of herbs, vegetables, rivers, forest resources among others, and by implication, it is worth noting the correlation between the physical and natural capital that sustain each other and aid the households with PLWHA survival patterns from the shock and stress of the HIV/AIDS pandemic.

In summary, it was observed that each of the capital is put into practice to complement or enhanced other forms of capitals and show the way to establishment of an appropriate livelihoods practices of the households. Hence, it is noted that social capital play fundamental role in accessing the different kinds of resources, social capital as the social networks among households in the villages which are built based 
on the affinity or kinship structure and cultural or ethnic perception. To this end, households with PLWHA uphold secured affiliation or relationship within the nearby households in the villages such as farming together, sharing of foods, settling disputes among the members of the villages, sharing of bicycles and motorcycles among others. Therefore, social networking is an essential condition for the livelihoods of households with PLWHA and possessing a good social network permit the households with PLWHA to produce patterns to improve their livelihoods. The table- 2 below illustrates the analysis of the capitals utilization for livelihoods among households with PLWHA:

Table-2: Analysis of Capitals utilization for Livelihoods among Households with PLWHA

\begin{tabular}{|c|c|c|c|c|c|c|}
\hline \multirow[t]{2}{*}{ Capitals Utilization } & \multirow[t]{2}{*}{ Primary Capitals } & \multicolumn{5}{|c|}{ Secondary Capitals } \\
\hline & & $\begin{array}{l}\text { Financial } \\
\text { Capital }\end{array}$ & $\begin{array}{l}\text { Human } \\
\text { Capital }\end{array}$ & $\begin{array}{l}\text { Social } \\
\text { Capital }\end{array}$ & $\begin{array}{l}\text { Physical } \\
\text { Capital }\end{array}$ & $\begin{array}{l}\text { Natural } \\
\text { Capital }\end{array}$ \\
\hline $\begin{array}{l}\text { Capitals utilized for Savings and } \\
\text { Land Accumulations }\end{array}$ & Financial Capital & & & & & \\
\hline $\begin{array}{l}\text { Capitals Utilized for Career } \\
\text { Opportunities }\end{array}$ & Human Capital & & & & & \\
\hline $\begin{array}{l}\text { Capitals Utilized for Problem } \\
\text { Solving and Communities } \\
\text { Engagement }\end{array}$ & Social Capital & & & & & \\
\hline $\begin{array}{l}\text { Capital Utilized for Households } \\
\text { Survival }\end{array}$ & $\begin{array}{l}\text { Natural Capital } \\
\text { Physical Capital }\end{array}$ & & & & & \\
\hline
\end{tabular}

Source: Qualitative Research, 2019

\section{DISCUSSION}

Livelihood patterns of households with PLWHA utilized a number of capitals to sustain them from the shock and stress of HIV/AIDS epidemic and capitals are the basis of households' livelihood development as noted by Anthony [12] that livelihood capitals are the source of households' livelihood advancement. Daskon and McGregor [13] noted that capitals are the prerequisite for sustainable households' livelihood progress and Meekaew and Ayuwat [14] stated that households are expected to utilize a number of livelihood capitals for their livelihood activities. Households give priority to their livelihood patterns by utilizing the available capitals according to their sociocultural patterns as observed by Chamber and Conway [15] that livelihood patterns of households give main concern to surviving preferences and see households as active managers who autonomously make a decision on their own livelihood pattern in connection with their social and cultural context. Thus, in the context of households with PLWHA, livelihood capitals utilization is fashioned to ensure households survival particularly households who have difficulties from their livelihood activities as observed by Saithong, Ayuwat and Chinnasri [16] that capitals utilization creates improved chances for living conditions.

It is pertinent to mention that capital utilization among households with PLWHA are diverse and in order to sustain the households, households with PLWHA get different incomes to survive and to cope from shock and stress of the HIV/AIDS pandemic. Therefore, households with PLWHA utilized different capitals to complement one another in order to attain their livelihood target. Each form of capital is put into practice as enhancement to other forms of capitals and by implication leading to the establishment of appropriate livelihood pattern for the households and it corroborates the work of Groenewald and Bulte [17] that increases of certain livelihood capitals diversifies household livelihoods and improve livelihood patterns. For instance, an enhancement in one capital leads to an enhancement in another, the more educated PLWHA become (human capital), and the more likely they are to get good jobs with good pay. The good pay means an increase in the financial capital of the households with PLWHA. Increase in financial capital implies that the households with PLWHA will upgrade their home with better facilities (increase in physical capital). The findings corroborates the scholarly assertions of Fang, Fan, Shen and Song [18]; Hua, Yan and Zhang [19]; Walelign, Pouloit, Larsen and Smith-Hall [20] and Wang, Yang, Wang and Zhang [21] that with household advancement, increase in households with PLWHA physical, financial, social, human and natural capitals prompt them to decide on the livelihood activities and accordingly achieve diversified livelihoods patterns or livelihoods transformation and the higher the accumulated livelihood capitals, the more likely the households with PLWHA will select a livelihood with higher income. To this end, this study discovered that households with PLWHA discovered that the level of capital utilization is diverse and by implication indicating that households are having different livelihood outcomes and it also reveals the diversity of livelihood patterns the household with PLWHA chooses to deal with different contexts.

In addition, the findings of this study shows that social capital is crucial function in accessing a range of capitals and it is assumed according to this study that social capital is seen as social networks 
among the households in the villages which are fashioned out based on the kinship system or structure along with ethnic awareness as noted by Suleiman and Ayuwat [22] that the socio-cultural patterns or practices of the people in Africa and Nigeria is communal in nature and based on strong kinship life and based on providing care to any sick member of the household as signs of kindness, love and loyalty that connect the household members. Thus, households with PLWHA uphold close affiliation with their fellow households in the surrounding villages in spite of the stigma attached to the HIV/AIDS pandemic such as interaction, sharing food, joint farming, and settling of disagreement or difference of opinion among households in these villages and by implication, it shows how important social capital is to households with PLWHA livelihoods as observed by Goulden, Adger, Allison and Conway [23] that higher households with social capital are able to diversify livelihoods; Mitra [24] that without social capital, accessibility to any form of livelihood is practically inconceivable. Duffy, Stone, Chancellor and Kline [25] pointed out that social capital increase business opportunities and leading to improve income.

The findings of this study depict that the type and accumulation of households with PLWHA livelihood capital bring to bear an influence on the households' alternative or option of different livelihood activities as elucidated by the scholarly assertions of Fang, Fan, Shen and Song [18] that the higher the natural and human capitals, the more likely the households would choose agriculture as their livelihood activities; Hunter, Mawrotzki, Leyk, Maclaurin, Twine, Collinson and Erasmus [26] that some households might work as temporary migrant workers in other areas; Islam, Yew and Viswanathan [27] that natural, social and physical capitals equally contributed significantly to the income of households; Du, Zhen, Yan and De Groot [28] that households can increase their income by increasing their financial capital and can reduce poverty rate among households.

\section{CONCLUSION}

This study concludes that capitals utilization for livelihoods among households with PLWHA have strong influence on household's livelihood choice or option. This study revealed the range of capitals utilized by households with PLWHA to sustain their livelihood activities despite the shock and stress of the HIV/AIDS pandemic. It is pertinent to mention that livelihood capitals can play both promoting and restricting roles. A particular kind of livelihood capital may perhaps limit households to choose livelihoods and the effective or valuable utilization of the other forms of livelihood capitals. The types of livelihoods and the effective utilization of livelihood capitals have significant impact on households with PLWHA incomes. The paper revealed that the forms and amount of livelihood capital have certain impact on the choice or option of livelihoods of households with PLWHA and household livelihood patterns suggest the utilization procedure and the effective use of livelihood capitals.

\section{RECOMMENDATIONS}

Based on the findings of this study, it is recommended that authorities need to train households with PLWHA on how to enhance their capacities on livelihoods capitals utilization effectively.

The government should come up with policies that can take care and support the live- hood activities of households with PLWHA.

Households with PLWHA need to be assisted with medication subsidy to reduce medical expenses and stress on the households capitals.

Households with PLWHA need to improve their skills for enhanced and broaden horizons utilization of capitals.

\section{ACKNOWLEDGMENTS}

This paper is a part of Ph.D. Dissertation titled "Livelihoods of Households with People Living With HIV/AIDS in Northern Nigeria". We would like to thank Research and Training Center for Enhancing Quality of Life of Working Age People, Faculty of Nursing, Khon Kaen University, Khon Kaen, Thailand and Labour and International Migration Center, Khon Kaen University, Khon Kaen, Thailand for their support.

The researchers would also like to thank all the key respondents who provided useful information for this research. We would also like to thank the Khon Kaen University Ethics Committee in Human Research based on the Declaration of Helsinki and the ICH Good Clinical Practice Guidelines for granting this research approval with reference no HE623051.

\section{REFERENCES}

1. Ayuwat, D., Saithong, S., \& Chinanasri, O. (2019). Determinants of Human Capital Accumulation of Female Migrants in the Destination. Journal of Social and Political Sciences, 2(2), 347-355.

2. Ayuwat, D., \& Chamaratana, T. (2014). The Role of Labour Broker Networks in Setting the Price of Working Abroad for Thai Migrant Workers. AsiaPacific Population Journal, 27(1), 1-28.

3. Selman, L., Simms, V., Penfold, S., Powell, R. A., Mwangi-Powell, F., Downing, J., ... \& Harding, R. (2013). 'My dreams are shuttered down and it hurts lots'-a qualitative study of palliative care needs and their management by HIV outpatient services in Kenya and Uganda. BMC Palliative Care, 12(1), 1-13.

4. Frantz, R. G., \& Murenzi, A. (2014). The Physical Activity Levels among PLWHA Receiving High 
Actively Antiretroviral Therapy in Rwanda. Sahara Journal, 10, 13-18.

5. The Joint United Nations Programme on HIV/AIDS (UNAIDS). (2016). Global AIDS Update. http;//www.unaids.org/sites/default/files/mediaassets/global-AIDS-update-2016.en.pdf. Accessed on $9^{\text {th }}$ February, 2018

6. World Health Organization (WHO). (2015). Global Tuberculosis Report 2015. http://www.who.int/publications/en. Retrieved 17th July, 2018.

7. Truong, V. D., Hall, C. M., \& Garry, T (2014). Tourism and Poverty Alleviation: Perception and Experience of Poor People in Sapa, Vietnam. J. Sustain. Tour, 22, 1071-1089.

8. Ellis, F. (1998) Household Strategies and Rural Livelihood Diversification. Journal of Development Studies, 35(1):1-38.

9. Ellis, F. (2000). Rural Livelihoods and Diversity in Development Countries. Oxford: Oxford Press.

10. Barbier, E. B., \& Hochard, J. P. (2014). Poverty and the Spatial Distribution of Rural Population. Policy Research Working Paper, No. WPS7101. Washington, DC. World Bank Group. http://documents.worldbank.org/curated/en.

Retrieved on 21st July, 2018

11. Carney, D. (2003). Sustainable Livelihoods Approaches: Progress and Possibilities for Change: London: Department for International Development.

12. Anthony, B. (1999). Capitals and Capabilities: A Framework for Analyzing Peasant Viability, Rural Livelihood and Poverty. World Dev. 27, 20212044.

13. Daskon, C., \& McGregor, A. (2012) Cultural Capital and Sustainable Livelihoods in Sri Lanka's Rural Villages: Towards Culturally Aware Development. J Dev Stud. 48, 549-563.

14. Meekaew, N., \& Ayuwat, D. (2019). Factors Influencing Livelihood Security among the Fishing Migrant Households at Places of Origin in Thailand. International Journal of Recent Technology and Engineering. 8(2S3), 1573-1579.

15. Chambers, R., \& Conway, G. R. (2005). 'Ideas for Development' London: Earthscan.

16. Saithong, S., Ayuwat, D., \& Chinanasri, O. (2018). Human Capital Accumulation of Rural Female Migrants and Occupation Mobility at Destination Area: A Case Study of Chonburi. International Journal of Engineering and Technology, 7(2.10) 80-85.

17. Groenewald, S. F., \& Bulte, E. (2012). Trust and Livelihood Adaptation: Evidence from Rural Mexico. Agric Hum Values, 30, 41-55.
18. Fang, Y. P., Fan, J., Shen, M. Y., \& Song, M. Q. (2014). Sensitivity of Livelihood Capital in Mountain Areas: Empirical Analysis Based on Different Settlements in the Upper Reaches of the Minijiang River, China. Ecol Indic. 38, 225-235.

19. Hua, X., Yan, J., \& Zhang, Y. (2017). Evaluating the Role of Livelihood Assets in Suitable Livelihood Strategies: Protocol for Anti-Poverty Policy in the Eastern Tibetan Plateau, China. Ecol Indic. 78, 62-74.

20. Walelign, S. Z., Pouloit, M., Larsen, H. O., \& Smith-Hall, C. (2017). Combining Households Income and Asset Data to Identify Livelihood Strategies and their Dynamics. J Dev Stud. 53, 769-787.

21. Wang, F., Yang, D. G., Wang, C. J., \& Zhang, X. H. (2015) The Effect of Payments for Ecosystem Services Programs on the Relationship of Livelihood Capital and Livelihood Strategy among Rural Communities in North Western China. Sustainability. 7, 9628-9648.

22. Suleiman, M. S., \& Ayuwat, D. (2020). A Qualitative Study of Stigma Experience by Households with People Living With HIV/AIDS in Kaduna State, Nigeria. Systematic Reviews in Pharmacy, 11(6)1320-1328.

23. Goulden, M. C., Adger, W. N., Allison, E. H., \& Conway, D. (2013). Limits to Resilience from Livelihood Diversification and Social Capital in Lake Social-Ecological Systems. Ann Assoc Am Geogr, 103, 906-924.

24. Mitra, A. (2008). Social Capital, Livelihood and Upward Mobility. Habitat Int. 32, 261-269.

25. Duffy, L. N., Stone, G., Chancellor, H. C., \& Kline, C. S (2016). Tourism Development in the Dominican Republic: An Examination of the Economic Impact to Coastal Households. Tour Hosp Res. 16, 35-59.

26. Hunter, L. M., Nawrotzki, R., Leyk, S., Maclaurin, G. J., Twine, W., Collinson, M., \& Erasmus, B. (2014). Rural Outmigration, Natural Capital and Livelihoods in South Africa. Popul Space. 20, 402-420.

27. Islam, G. M. N., Yew, T. S., \& Viswanathan, K. K. (2014). Poverty and Livelihood Impacts of the Community Based Fisheries Management in Bangladesh. Ocean Coast. Manag. 96, 123-129.

28. Du, B. Z., Zhen, L., Yan, H. M., \& De Groot, R. (2016). Effect of Government Grassland Conservation Policy on Household Livelihoods and Dependences on Local Grasslands: Evidence from Inner Mongolia, China. Sustainability. 8, 1314. 